\title{
THE PROVENANCE OP TILLS OVERLYING THE EASTERN PART OF THE SOUTH MOUNTAIN BATHOLITH, NOVA SCOTIA
}

\author{
R.M. Graves and P.W. Finck \\ Nova Scotla Department of Mines and Ener $8 Y$ \\ P.O. Box 1087, Hallfax, Nova Scot1a B3J $2 \times 1$ \\ Date Rece1ved October 20, 1987 \\ Date Accepted April 29, 1988
}

\begin{abstract}
Mapping of quarternary deposits on the South Mountain Batholith (SMB) has resulted in a four-fold subdivision of t11ls, divided primarily on the basis of clast 11thology, texture, stratigraphic position and morphology.

Three t111s have clast 11thologies character1zed by granites eroded from the South Mountain Batholith. The oldest granite t1ll is a compact t111 of restricted distribution, mainly observed in drumlin cores. Two younger granite t111s dominate the surficial deposits of portions of the SMB and have textural properties ascribed to melt-out tills. The fourth $t 111$ represents a farther-travelled t111 with a varlable clast provenance typified by pebbles derived from both the SMB and regions to the north. Clast dispersal evidence suggests that all tills were transported in a general southward direction.

Detalled clast examinations allow rellable conclustons concerning direction of 1ce flow and lithologic relationship between t111 and bedrock of the SMB. The SMB is an area of multiple glaciation where t111 prospecting cannot be
\end{abstract} successful unless the direction of $t 111$ transport and source areas are established.

Un levé cartograph1que des depôts quaternafres recouvrant le Batholite de South Mounta1n a permis de mettre en évidence quatre variétés de tills en fonction de la 11thologie des clastes, la texture, la position stratigraphique et la morphologie.

Dans trols t11ls, les clastes montrent des 11thologies caracterisées par des gran1tes arrachés au Batholite de South Mountain (BSM). Le plus vieux t111 de gran1te est un t111 tassé, de faible étendue, observe surtout dans les noyaux de drumlins. Dans certaines portions du BSM, les depôts de surface sont dominés par deux tills de granite plus récents qui possédent des caracteristiques texturales rapportées aux tills d'ablation. Le quatrième till a parcouru une plus grande distance; la source de ses clastes est varlable et comprend typiquement des galets provenant tant du BSM que des régions plus au nord. La dispersion des blocaux suggere un direction genérale de transport des t1lls vers le sud.

Un examen approfond1 des clastes permet de tirer de solides conclusions à propos de la direction de 1 'écoulement glaclaire et de la relation 11thologique entre le till et le socle du BSM. Le BSM a subi de multiples glaciations et la prospection du t111 n'y est donc guere profitable a moins de determiner la direction de transport et la source du t111.

[Traduit par le journa1]

\section{INTRODUCTION}

The glacial geology of the South Mountain Batholith has been influenced by four ice flow phases (Finck and Graves, 1987a). Each ice flow has formed (or modified pre-existing tills to form) a till with 11 thic and chemical properties related to the source rocks. It is essential that tills deposited by different ice flows be distinguished so that interpretations of geochemical and clast dispersal data from the different flows are not confused. Podolak and Shilts (1978) and Stea and O'Reilly (1982) have confirmed the importance of this concept by showing that $t 111$ geochemistry is strongly controlled by clast geology and, hence, provenance.

This paper describes surficial deposits overlying the eastern part of the South Mountain Batholith (Fig. 1). Till classification and division is accomplished using directions of clast transport, clast 1ithology, stratigraphic position, color, texture and morphology. Emphasis will be placed on describing the directions of clast transport from t111 11thology and the spatial relationship between till and bedrock source. Physical properties of the tills such as color, texture and morphology wi11 be presented so that these may be utilized during field mapping.

\section{PREVIOUS WORK}

In mainland Nova Scotia, the succession of glacial movements as interpreted from till deposition is we11 documented. A compact t111 of restricted occurrence, mapped at the base of drumlins, is the oldest t111 in the Meguma Zone. Stea and Fowler (1979) designated this till the Hartlen Till where it overlies Meguma Group rocks, and discovered the clasts to be dominated by Meguma Group 11thologies. They concluded that the Hartlen T111 is 90-95\% 1ocally derived with 5-10\% foreign clasts. Grant (1963) had also described it as being locally derived with only minor dilution by exotic pebbles. It was termed a lodgment till by Nielsen (1976), deposited during an uninterrupted glacial sequence that occurred during Mid-Late Wisconsinan glaciation. The Hartien Till is correlative with the McCarron Brook Till of Stea et al. (1985) and was formed by an east-southeastward ice flow (phase one of Stea and Finck, 1984).

The Hartlen Till is succeeded by the Lawrencetown T111 (Grant, 1963; Grant, 1975) which was deposited 


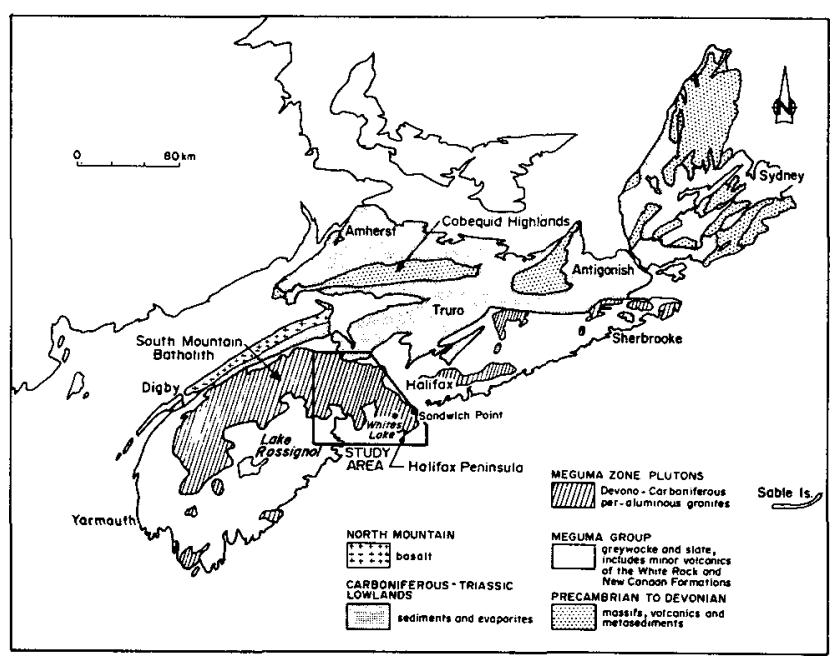

F1g. 1. Generalized geology map of Nova Scotia showing the study area.

by a southeastward to southward 1ce flow (phase two of Stea and Finck, 1984). The Lawrencetown Ti11 was first mapped in detall by Grant (1963) who Identifled seven 'red clay' drumlin flelds in Nova Scotia extending from Lunenburg County to Guysborough County. He noted increased levels of foreign 11thologies associated with the drumlins and believed the far-travelled clasts were dispersed southward to southeastward from sources in North Mountain, Carboniferous lowlands and the Cobequid Highlands.

Tills having a clast composition controlled by bedrock 11thologies originating within the South Mountain Batholith and the encompassing Meguma Group rocks have been described by Prest (1896), Grant (1963) and Stea and Fowler (1979). They observed the close relationship that granite, slate and greywacke tills of this region have with the underlying bedrock and concluded that t11ls dominated by a particular 11thology overlie bedrock of that same 11thology. These tills, formed during lce flow phases 3 and 4 of Stea and Finck (1984), have been related to radiating ice centers moving in diverse directions from upland areas in Nova Scotia.

\section{FIELD METHODS}

T111 cuts were examined along highways, secondary roads and the seacoast. Mapping was supplemented by $t 111$ and clast sampling on a square $2 \mathrm{~km}$ grid pattern. This sample separation was used for the following reasons: (1) to sample the South Mountain Batholith (SMB) at the greatest possible density and obtain the maximum amount of 11thologic and t111 information while meeting the time 1imitations of the project; (2) the clast data was intended for use by the bedrock mapping members of the survey to ald in determining bedrock type and delineating bedrock contacts where exposure is lacking. A significantly larger t111/clast sampling grid may have had a coarser separation than the actual occurrence of bedrock outcrop, thereby decreasing the usefulness of the clast counting study; and (3) the sampling grid also served as a regional till geochemical survey. It was felt that a $2 \mathrm{~km}$ spacing had a reasonable chance of intersecting mineral dispersal trains based on previous knowledge of tin dispersal at East Kemptville (Stea and Grant, 1982) and tungsten dispersal at ShIp Harbour (MacG1111vray, 1983).

Clast Identification was conducted on pebbles extracted from till in the fleld. Plastic sieves having $1.25 \mathrm{~cm}$ openings were used to separate clasts and t111 matrix. Clast data assists in identifying the magnitude and direction of $t 111$ dispersal and to quantify the 11thologic composition of the till. Pebbles were divided into three principal groups: granitoid, Meguma Group and foreign 1ithologies. The granitolds, derived from the SMB, were further sub-divided visually (after MacDonald et al., 1987) into units using texture, grain size, alteration, color, and modal percentages of biotite, muscovite, quartz, and the feldspars. Meguma Group clasts were further subdivided into greywacke and slate. The forelgn category of pebble types includes volcanic rocks, mafic and intermediate intrusive rocks, sandstones, siltstones, metasedimentary rocks and quartz. This classification contains pebbles that commonly have unknown provenance and may Include Meguma Group clasts of unusual colour and alteration that are difficult to discriminate from Cobequid Highland metasedimentary rocks.

A genetic classification after Drelmanis (1976) has been applied to some units. Lodgment tills (Granite Till A) on the SMB are characterized by high compaction, a clast content dominated by local 1ithologies and the development of fissility and sub-horizontal fault planes that may exhibit slickenslides. Melt-out t111s have a loose texture and exhibit sorting structures as described in Shaw (1982). In this survey, ablation t111 (Granite T111 C) was distingulshed from ground moralne (Granite T111 B) by hummocky morphology and an abundance of me1t-water related structures such as planar-bedded sand and boulder scours. Clast types in the ablation till are generally more varled and are transported from a more distant and larger area than Granite T111 B. The latter also lacks the irregular knobby morphology of the ablation till and is, instead, expressed as a low rellef ground moraine resulting from deposition by active receding ice (Graves and Finck, 1988).

\section{STRATIGRAPHY}

The stratigraphic relationships between $t i 11$ units are, in general, poorly exposed in the study area; however, observations generally agree with the work of previous authors. Till sequences are best observed in drumlin sections exposed along the coast or in gravel pits. Mapping superimposed tills (F1g. 2) is vital to determine relative ages of 1ce advances. During the survey, exposed drumlins were examined to ascertain the sequence of glacial deposition and the nature of internal contacts. Till fabric analysis was performed on selected sections to aid the clast provenance studies and to determine ice flow directions.

A complete sequence of tills in superposition representing Wisconsinan glaciation in Nova Scotia has not been recognized on the SMB. Loose, sandy t111s are commonly seen overlying Granite T111 A and the Lawrencetown T111, but Lawrencetown T111 has not been mapped overlying Granite Till A. Three of the most important sections studied by the 


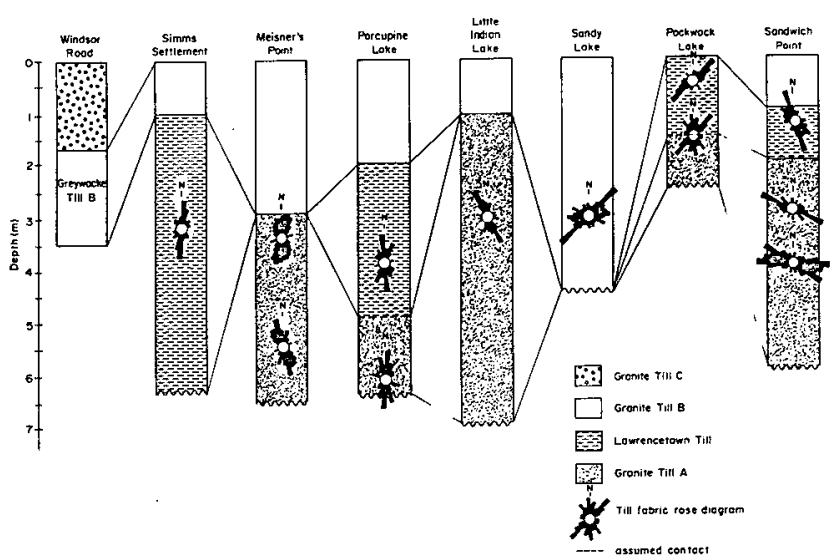

Fig. 2. Till stratigraphy on the eastern South Mountain Batholith. Rose diagrams show the fabric orientation within the t111 units.

authors are described below.

\section{Sandwich Point Section}

A wave-cut drumiln at Sandwich Point exhibits a nearly complete stratigraphic sequence. The uppermost portion of the section reveals Granite Till B, a very stony till in which the clasts are comprised entirely of angular boulders of Halifax Peninsula Leucomonzogranite (MacDonald et al., 1987) derived from underlying bedrock. This tili grades into a zone containing angular granite and subangular greywacke clasts, which in turn overlies a sandy washed greywacke-rich diamicton interpreted to have been derived from the underlying Lawrencetown T111. In a classic succession, Granite Till A would underlie the Lawrencetown T111, whereas at this locality the stratigraphic position is filled by a compact. Meguma-rich till resembling the Hartlen Till. This is unusual, as the Hartlen T111 and Granite T111 A are lateral equivalents and derived from the Meguma Group and South Mountain Batholith, respective1y. This is the only location where Hartlen T111 was observed overlying the SMB. The Meguma Group-granite contact is only two hundred metres to the east, suggesting a nearby source for the Hartlen Till. Underlying the Hartlen Till, at Sandwich Point, is residual granite believed to be of pre-Wisconsinan age, pre-dating all tills in the province.

\section{Simms Settlement Section}

An excavated drumlin at Simms Settlement reveals the stratigraphic relationship between Granite Till $B$ and Lawrencetown Ti11. Bouldery Granite Ti11 B overlies the Lawrencetown Till and continues laterally along the ground surface. Wedges of granite t111 are injected into the lower till. An attitude was not determined for these wedges; however, Nielsen (1976) noticed the same structures in a section at White's Lake, Halifax County. Nielsen observed that the t111 wedges dip $45^{\circ}$ to the south-southeast, implying injection into the lower till by overriding lce flowing in the same direction.

\section{Windsor Road Section}

Ablation t111 of SMB provenance (Granite T111 C) overlies a 1ocal, stony t111 (Greywacke Ti11 B) derived from greywacke bedrock, at Windsor Road, Lunenburg County. It is a washed till with assoclated stratified drift and is considered the youngest ti11 unit mapped. Granite Ti11 C contains boulders of biotite monzogranite belleved to have been eroded from Sandy Lake Monzogranite inliers 10 $\mathrm{km}$ to the northeast. This suggests that the t111 was formed by ice flowing to the southwest.

\section{TILL UNITS}

\section{Granite Ti11 A}

Finck and Graves (1987a) mapped Granite T111 A coring drumlins north of The Head of St. Margaret's Bay at Meiseners Point and at Little Indian Lake (Fig. 3). It is a compact, moderate brown till commonly displaying sub-horizontal fissility. In drumlin sections the till varies from 3-10 $\mathrm{m}$ thickness and is always overlain by 1-2 $m$ of loose, granitic till.

Granite Till A, in a drum1in $700 \mathrm{~m}$ west of Little Indian Lake, contains a clast population representative of the immediate bedrock geology (F1g. 4b). The drumlin is situated near a bedrock contact between Sandy Lake Monzogranite (SLM) and Tantallon Leucomonzogranite (TL). The variation in granitic clast percentages within the t111 is minimal. For instance, the SLM content varies from 45-65\% and the TL content varies from $20-30 \%$. Meguma Group and foreign clasts constitute a significant proportion of the till, varying from $6 \%$ near the contact with the upper unit to $33 \%$ at $4 \mathrm{~m}$ depth. Granite Till A is also exposed in a road cut on Highway $\|_{103} 3 \mathrm{~km}$ southwest of the Little Indian Lake section ( $\mathrm{F} 1 \mathrm{~g}$. 4a). It contains 40-55\% clasts from the underlying TL, but also $15-30 \%$ clasts from the SLM which is located $4 \mathrm{~km}$ north of this section. As in the drumlin at Little Indian Lake, the lower $t 111$ contains Meguma Group and foreign clasts. Grante Till A is consistently dominated by local granites while hosting farther travelled non-granitic clasts.

Peltoniemi (1985) described clast uptake in t111 using renewal distance which is the distance (measured in the down-ice direction from a bedrock contact) over which a down-1ce rock type increases from $0-50 \%$ in the till. It is applied here to give a numerical value to the rate of incorporation of clasts into the till. Renewal distances are calculated after Salonen (1986) using clast count data collected in the field. In Granite Ti11 A, the renewal distance varies from $1.7 \mathrm{~km}$ to $2.4 \mathrm{~km}$.

The clast geology in Granite T111 A at Little Indian Lake indicates southward dispersal and is consistent with southeastly till fabric data. The physical properties, clast 11thology and stratigraphic level suggest Granite Till A was formed during ice flow phase 1 of Stea and Finck (1984).

\section{Lawrencetown $\mathrm{T} 111$}

The Lawrencetown T111 is a reddish-brown muddy till (Plate 1) of partial exotic provenance that forms drumlins separated by a ground moraine (Fig. 8). The drumlins vary in thickness from 3-10 $\mathrm{m}$ and the ground moraine from 1-3 m. A varlation in mud content modifies the texture from cohesive in the 


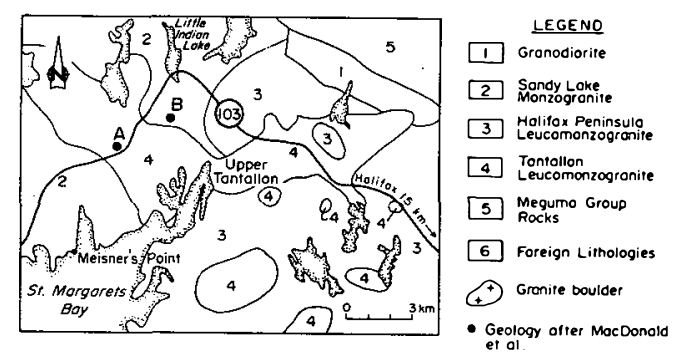

Fig. 3. Location of till sections $A$ and $B$ in relation to bedrock of the South Mountain Batholith.

TILL SECTION A

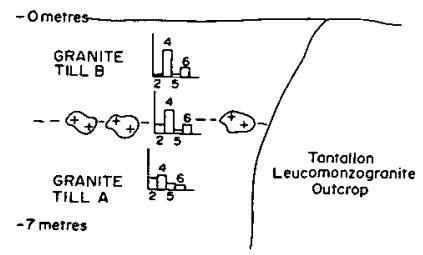

F1g. 4a. T111 section A exposed along Highway \#103. Histograms represent the clast types observed at pebble count sites. The bar numbers are keyed to the bedrock geology in Figure 3.

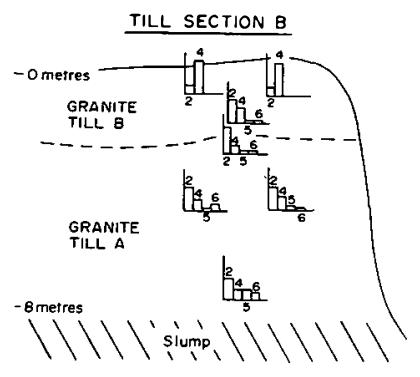

Fig. 4b. Till section B exposed west of Little Indian drumlin t111 to a looser, sandier texture in the ground moraine. Lawrencetown T111 drumlins contain $60-90 \%$ clasts from north of the SMB and the ground moraine contains 40-60\% non-granitic pebbles. Lawrencetown T111 lacks till hummocks and glaciofluvial deposits indicating basal deposition and only a slight influence on the till by glacial me1t-water.

Detalled clast examinations by the authors indicate Lawrencetown Till was derived from a distant source. Mapping of the Lawrencetown $\mathrm{T} 111$ on the South Mountain Batholith has shown that much of the clast and matrix of the Lawrencetown Till is derived from north and northwest of the druminized areas. Clasts in this till on the Halifax Peninsula are Meguma Group slates and greywackes, Carboniferous sedimentary rocks and Cobequid Highlands volcanic and intrusive rocks. The Lawrencetown T111 must have crossed the Cobequid Highlands, Minas Sub-basin and Meguma Group bedrock to have entrained a pebble assemblage of this type with transport distances up to $90 \mathrm{~km}$ from the Cobequid Highlands (Finck and Graves, 1987a). Indicator clasts derived from the Cobequid Highlands are spherulitic rhyolite from the Fountain Lake Group and diorite from the DevonoCarboniferous plutons coring the Highlands (P.J. Wallace, personal communication).

South of Windsor, Hants County (Fig. 5a) the Lawrencetown $\mathrm{T} 111$ has a far-travelled clast provenance that is distinct east of Leminster in comparison with the area to the west (Fig. 5b). East of Leminster, Lawrencetown T111 contains $0-30 \%$ sedimentary rocks from the Minas Sub-basin and 0$10 \%$ basalt clasts of North Mountain provenance. T111 in this area has clast renewal distances as large as $70 \mathrm{~km}$. The Carboniferous sedimentary rock concentrations over the SMB decreases to $<5 \%$ south and west of the western terminus of the Carboniferous Basin. Simultaneous1y, the basalt percentages increase quickly in this area of the

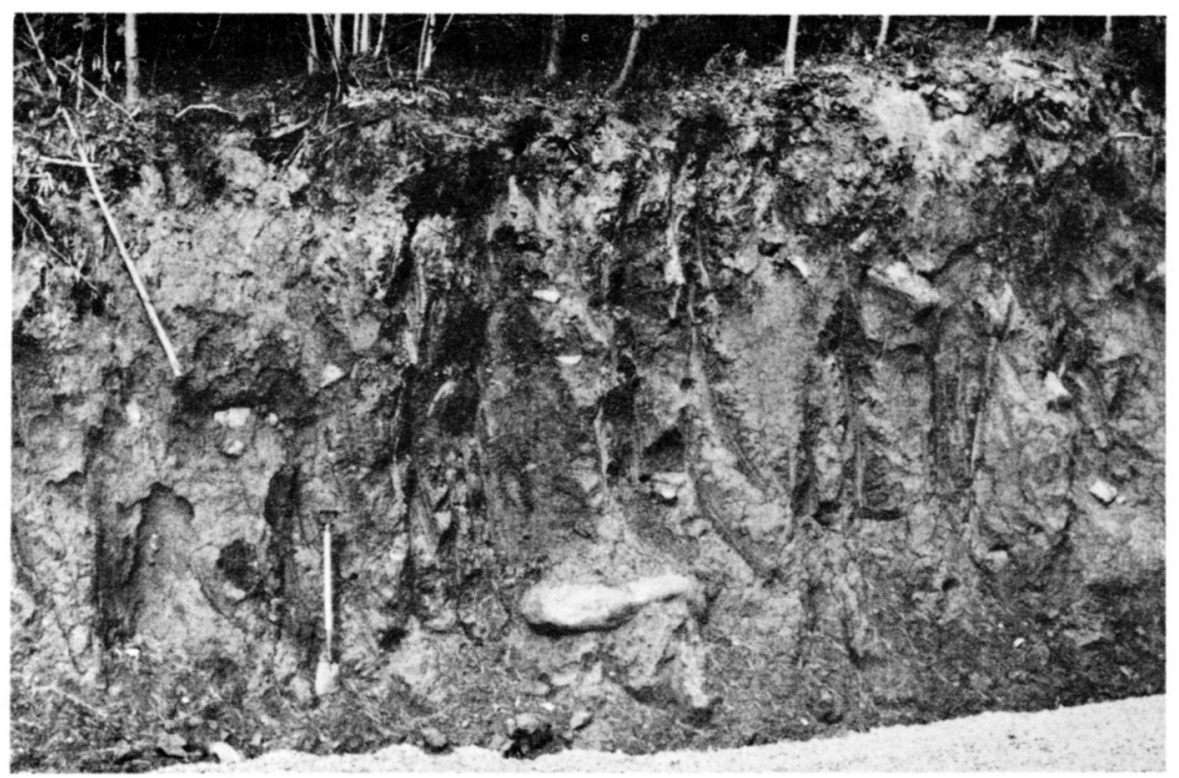

Plate 1. The Lawrencetown Till, a reddish-brown, muddy till containing clasts of local and distal provenance. 


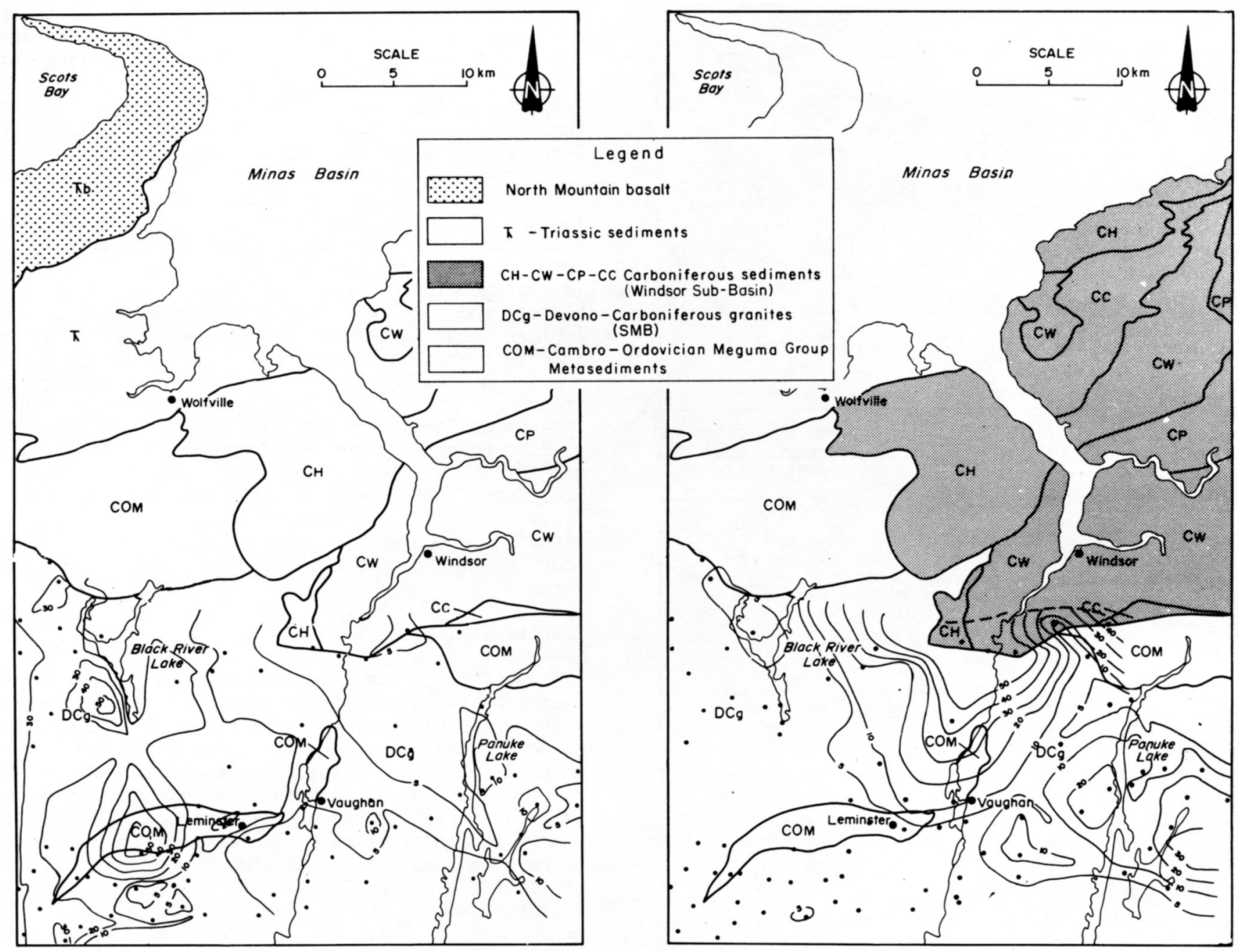

Fig. 5a. Clast lithology map showing the contoured percentages of North Mountain basalt clasts in Lawrencetown Ti11.

SMB from 0-50\%. The decrease in clastic rock types and the abrupt increase in basalt suggests that ice forming the Lawrencetown Till flowed south across this region.

Lawrencetown T111 is usually described as fartravelled because of the high foreign clast content and its red muddy appearance. However, Lawrencetown Till also contains a significant local clast content. North of New Ross, the authors have observed New Ross Leucomonzogranite (NRLM) and Panuke Lake Leucomonzogranite (PLLM) clasts displaced from bedrock to the till surface within 500 metres (Figs. 5c, d). Though the uptake is abrupt, the granite till clasts do not achieve percentages greater than $56 \%$ in the till. Renewal distance for clasts in this area vary from $2.5 \mathrm{~km}$ to $5 \mathrm{~km}$.

Lawrencetown Till contains clasts from multiple SMB bedrock sources. This is 11lustrated $6 \mathrm{~km}$ north of New Ross where Salmontail Monzogranite is in intrusive contact with a Meguma Group greywacke inlier ( $\mathrm{Fig} .6$ ). The maximum down-1ce displacement of these granite clasts cannot be determined, however. Salmontall Monzogranite decreases to approximate1y $15 \%$ of the clast content $4 \mathrm{~km}$ downice of this contact. These clasts were eroded and

F1g. 5b. Clast 1ithology map showing the contoured percentages of Carboniferous sedimentary clasts in Lawrencetown Till.

deposited in a basal-ice position in the Lawrencetown T111 where the rate of comminution is high. This contrasts with the long dispersal distance of foreign lithologies which are transported in an englacial position prior to deposition. The influx of foreign material also serves to dilute the local component.

\section{Granite Till B}

Granite Ti11 B is a yellowish-brown, bouldery and immature till (Plate 2). The till forms a flat to undulating ground moraine (Fig. 7) that varies in thickness from 1-6 m. It exhibits limited clast dispersal and, therefore, can be divided into lithological facies that correlate with underlying bedrock.

The close spatial relationship between granite clasts in Granite Ti11 B and the corresponding granite bedrock geology is seen on Figures $8,9 a$, $9 b$ and $9 c$. The lithology maps are contoured plots of the major granite clast types found in the till and the bedrock geology is after Corey (1988). Granite clasts are divided into three categorles and contoured with a $25 \%$ interval. Comparison of the contoured plots with bedrock geology indicates 


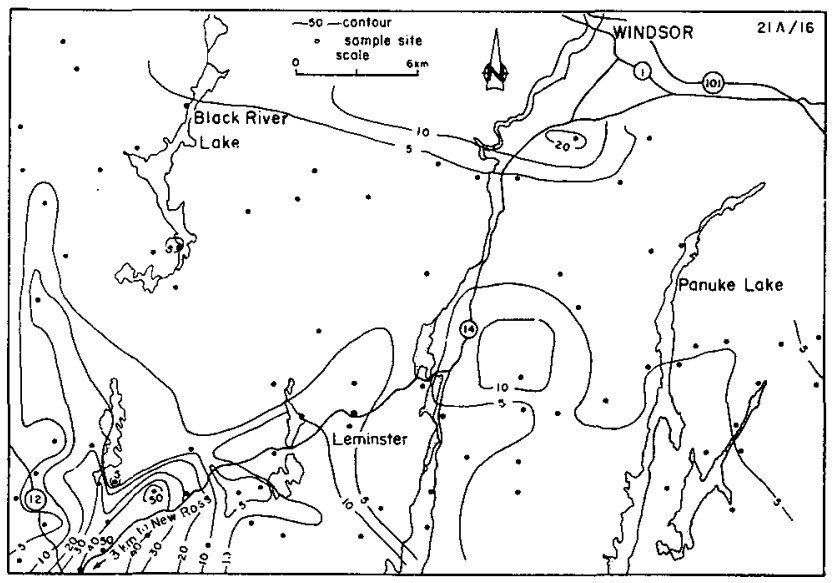

Fig. 5c. Clast 11thology map showing the contoured percentages of Panuke Lake Leucomonzogranite and Lake Lewis Leucogranite clasts in Lawrencetown Till.

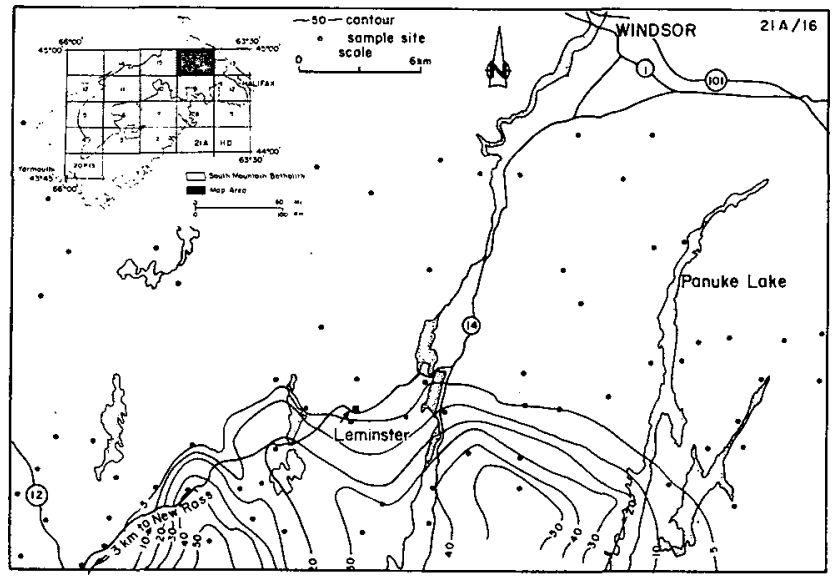

Fig. 5d. Clast 11thology map showing the contoured percentages of New Ross Leucomonzogranite clasts in Lawrencetown Till.

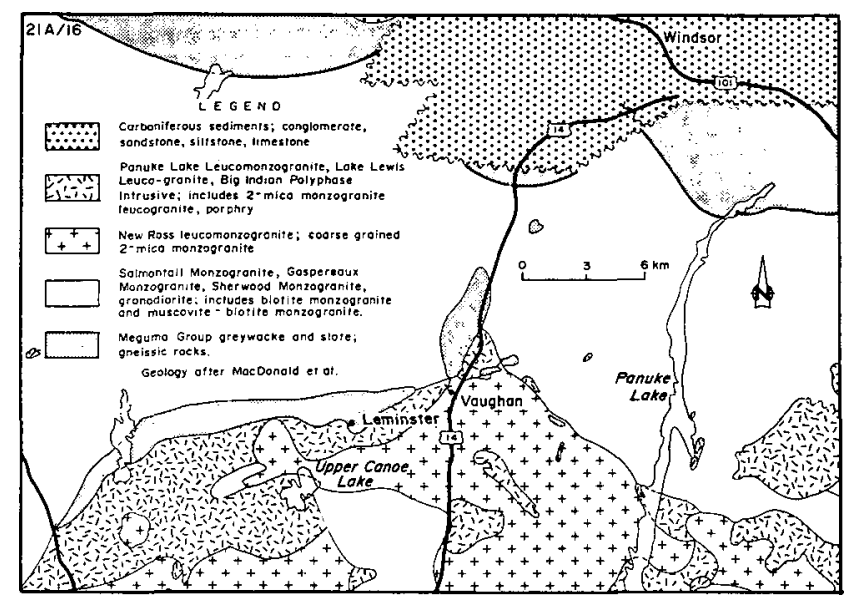

Fig. 6. Bedrock geology of the Windsor mapsheet.

1ittle overlap of granites southward across adjacent rock types in quantities of clasts greater than 25\%. For example, east of Spondo Lake and northeast of Chester large areas of Sandy Lake Monzogranite (SLM) are overlain by till dominated $(75-100 \%)$ by SLM clasts (F1g. 9b). There appears to be 1ittle evidence of dilution by rock types found up-ice, 1.e., to the north. West of Connzught Lake, two sma11 inliers of SLM $1 \mathrm{~km}$ and $6 \mathrm{~km}$ are overlain by Granite Till B consisting of 75-100\% SLM clasts confirming the restricted dispersal within the t111 sheet. Renewal distances for clasts, as determined by field mapping, in Granite T111 B are tens to hundreds of metres.

Numerous bodies of Tantallon Leucomonzogranite (TL) intruded the SLM and NRLM. These plugs vary in area from $1 \mathrm{~km}^{2}$ to $50 \mathrm{~km}^{2}$ and have an overlying t111 sheet generally comprising $75-100 \%$ of clasts incorporated into the till ( $\mathrm{F} 1 \mathrm{~g}$. 9c) from these late-stage intrusions. The small size of the bodies and limited down-ice dispersal $(<1 \mathrm{~km})$ implies that input of bedrock into the $t 111$ is immediate and that the transport distance is short. 1.e., a few hundred metres. Determining a transport direction using clast dispersal in this till is difficult. Clast sampling was performed on a $2 \mathrm{~km}$ grid and clast displacement in this t111 is significantly less than the sample spacing. Therefore, the sampling grid may not intersect clast dispersion from a small granitic body situated equidistant between sample sites and this body would be undetected in the clast sampling survey.

\section{Granite T111 C}

Granite Till C is a yellowish-brown, loose, sandy ablation t111 exhibiting bedded sands intermixed with t111 (P1ate 3). Granite Ti11 C exists as a discontinuous moraine of isolated mounds and merging hummocks forming ridges (Fig. 7) which distinguishes areas underlain by this till from the generally flat landscape of Granite Till B. The ridges are interpreted to be the result of pushing by re-advancing ice fronts and are ice marginal and transverse to ice flow (Graves and Finck, 1988). Pebbles vary in angularity from angular to subrounded. This till is dominated by clast 1ithologies derived from the SMB. In examined exposures, it contains pebbles from underlying bedrock in proportions ranging from $0-70 \%$. Further travelled clasts include Meguma Group rocks from 5$20 \mathrm{~km}$ distance and other SMB granitoid 1ithologies.

Unilke Granite Ti11 B, this till has appreciable clast transport and as such a direction of flow can be determined using clast dispersal evidence. Deposits of Granite T111 C are primarily concentrated at Gold River, Dauphinees Mill Lake, and north and east of Chester (Fig. 8). The ablation ti11 at Dauphinees M111 Lake is a mixture of SLM, TL and Meguma Group rocks. Dispersal of the Meguma Group clasts, source of which is believed to be $20 \mathrm{~km}$ northeast of Dauphinees $\mathrm{Mill}$ Lake, is based on the southwestward-trending till fabric evidence at Sandy Lake and Pockwock Lake (Finck and Graves, 1987a, b), southwest-northeast orlented striations (Finck and Graves, 1987a, b) and Pleistocene mapping by other workers. A late Wisconsinan westward flow was mapped by Stea (1982) and Prest et al. (1972) in the Minas Sub-basin. Southwestward-trending erosional and depositional indicators of ice flow on the SMB may be a deviation of this westward advance to the southwest and onto the SMB. This southwestward flow formed Granite Till C in this area while dispersing Meguma Group clasts $20 \mathrm{~km}$ from the source.

Northwest of Chester, the dispersal of Spectacle 


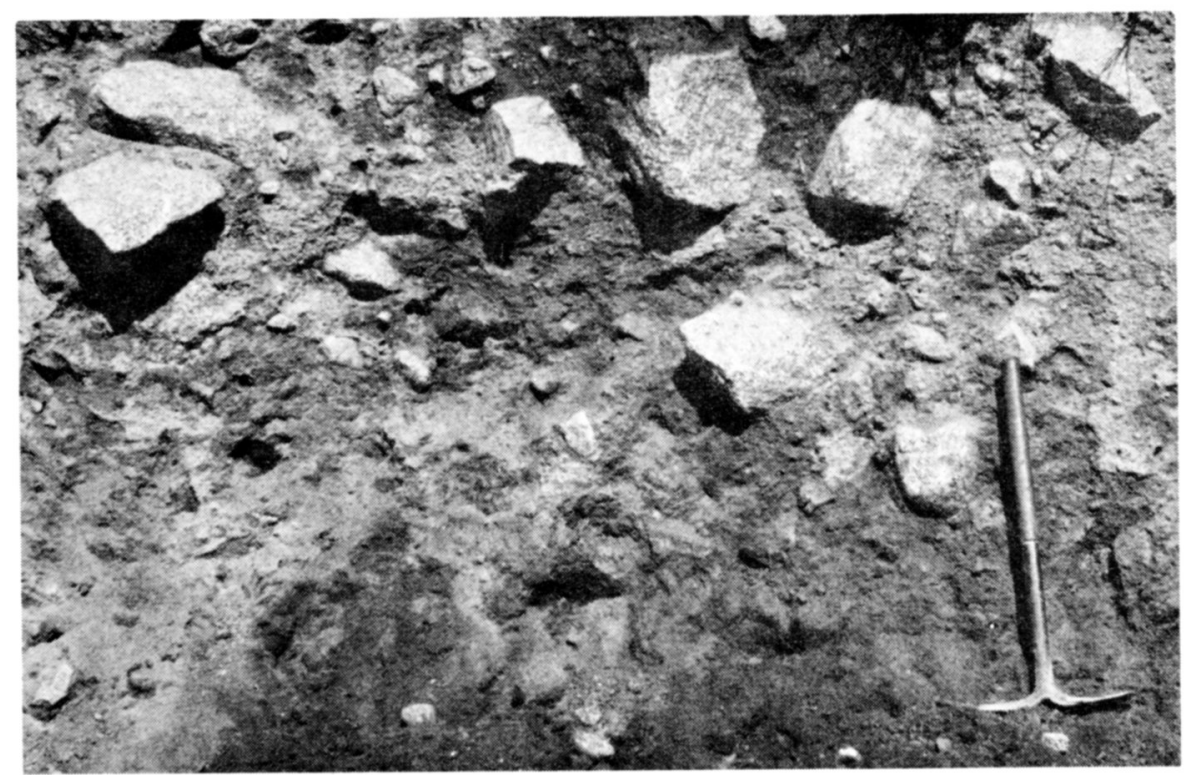

Plate 2. Granite Till B exposed at Simms Settlement. The clasts in this t111 are derived entirely from Sandy Lake Monzogranite which is the bedrock geology of the area. The stoniness of Granite Till B and the angular clasts attest to the immature nature of the till.

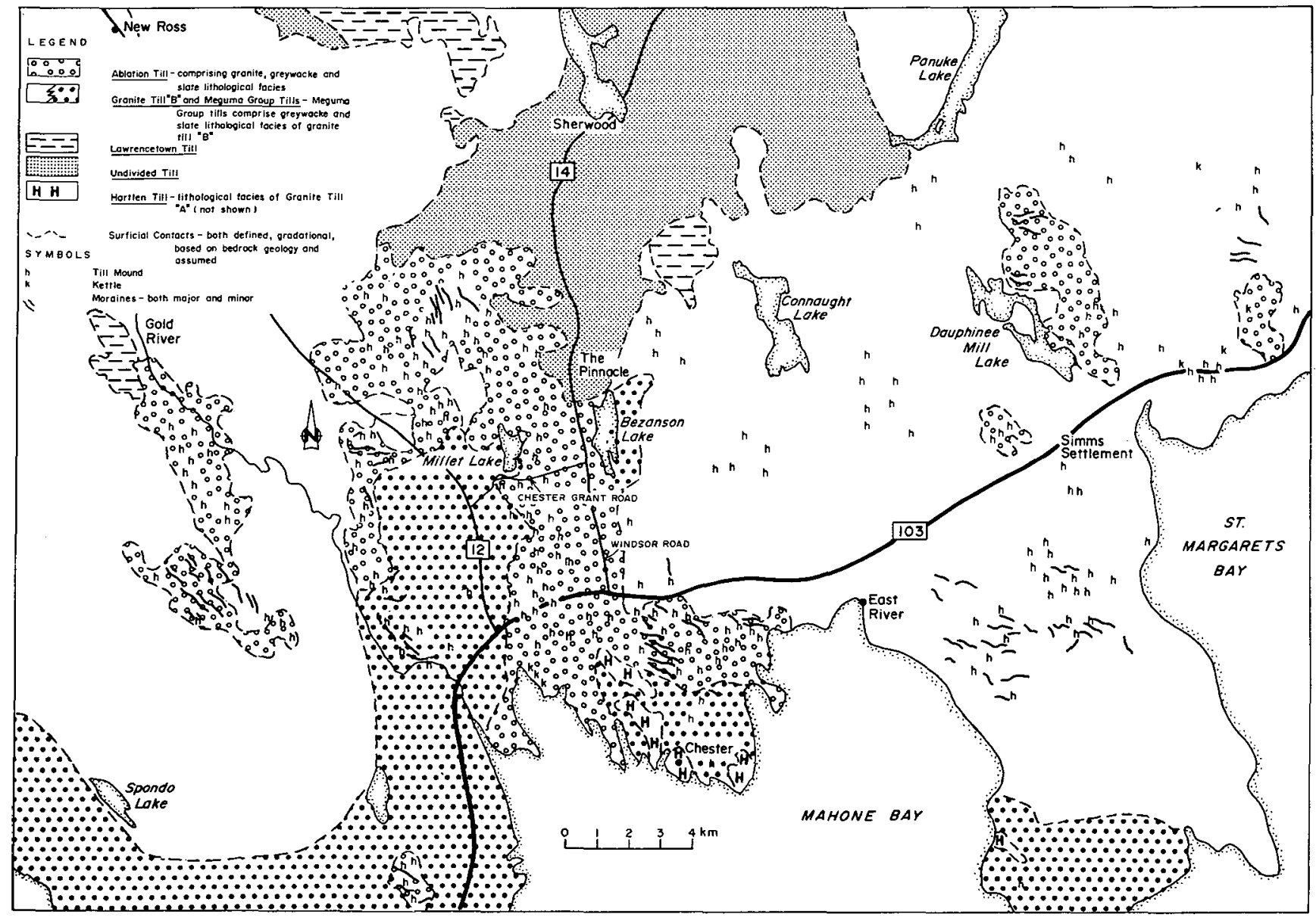

Fig. 7. Surficial geology of the Chester mapsheet. 

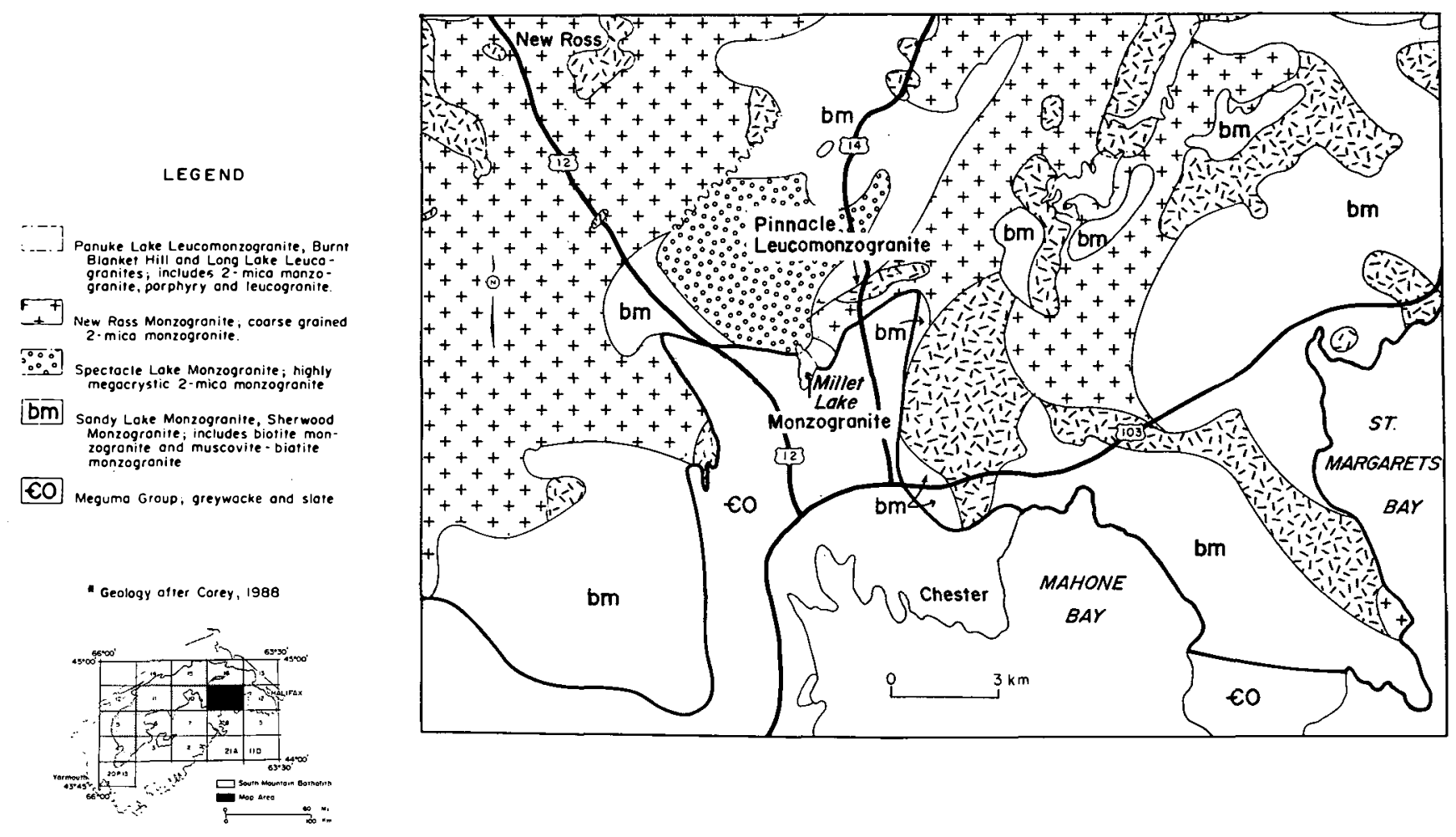

Fig. 8. Bedrock geology of the Chester mapsheet.

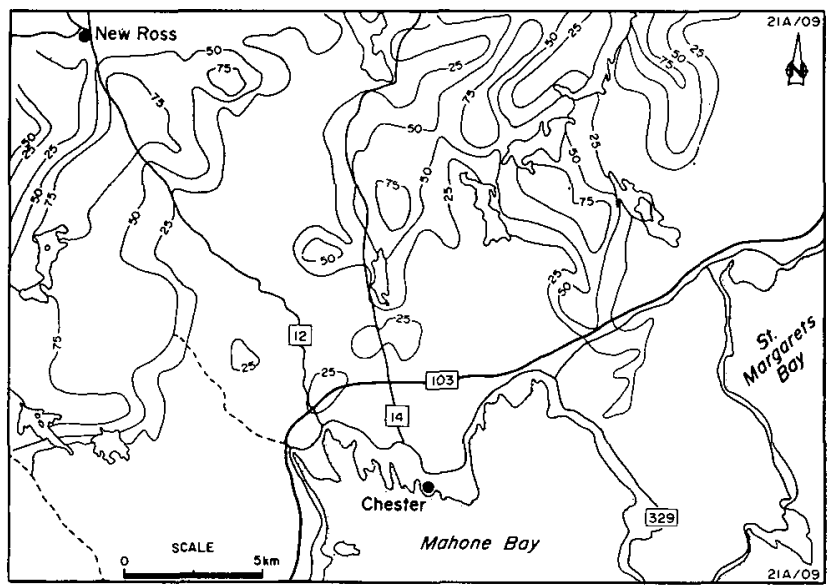

Fig. 9a. Clast lithology map showing the contoured percentages of New Ross Leucomonzogranite clasts in Grantte T111 B and Granite T111 C. The area shown is the Chester mapsheet.

Lake Leucomonzogranite clasts in Granite Ti11 C Indicates a different flow direction towards the south-southeast (Fig. 10). The onlap of these granite clasts onto greywacke bedrock is at least 5 $\mathrm{km}$ and renewal distances vary from approximately $300 \mathrm{~m}$ to $6 \mathrm{~km}$. Within this dispersal fan, other distinctive rock types are also displaced southward. Two $\mathrm{km}$ south of Millet Lake, an excavated till hummock contains $60-80 \%$ of the Millet Lake Monzogranite, The intrusive plug is sma11 (approximately $1 \mathrm{~km}^{2}$ ) and provides a precise location for determining source and flow direction. Clasts from the Pinnacle Leucomonzogranite show a similar dispersal fan. On the Chester Grant road, stratified till contains $50 \%$ fine- to medium-

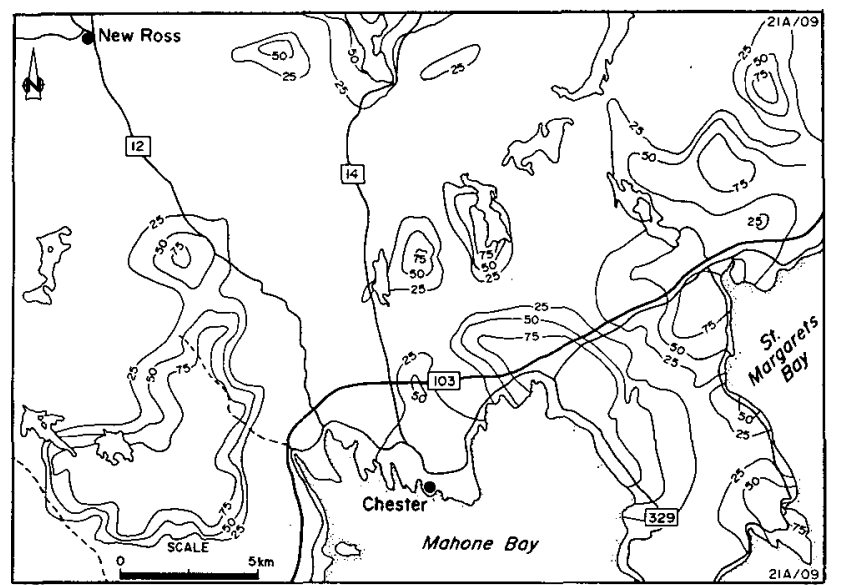

Fig. 9b. Clast 11thology map showlng the contoured percentages of Sandy Lake Monzogranite clasts in Granite T111 B and Granite T111 C.

grained leucomonzogranite clasts derived from a small intrusive body at The Pinnacle and $50 \%$ pyritic slate from the Halifax Formation. The location of this till cut is over greywacke bedrock and is $2 \mathrm{~km}$ south of the western contact of the Pinnacle Leucomonzogranite with New Ross Leucomonzogranite.

\section{CONCLUSIONS}

An extensive 1ithologic study of clast abundances and types in the tills of the SMB have allowed the authors to produce till clast 1ithology maps which portray valuable information regarding till provenance and till dispersal. The authors have 


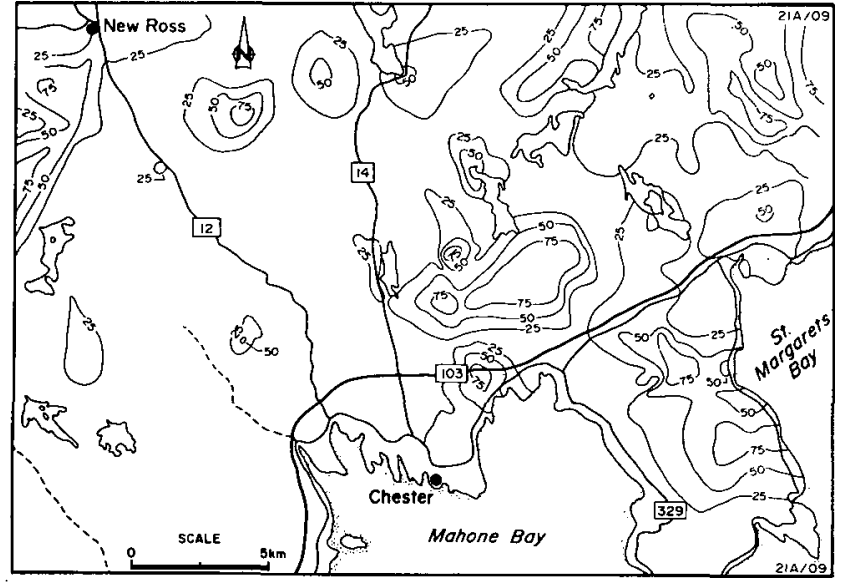

Fig. 9c. Clast 11thology map showing the contoured percentages of Panuke Lake Leucomonzogranite and Long Lake Leucogranite clasts in Granite T111 B and Granite Ti11 C.

determined that the surficial geology of the study area hosts four ti11s: Granite Ti11 A, Lawrencetown Ti11, Granite Ti11 B and Granite Till C. Lawrencetown Ti11, Granite Ti11 B and Granite Till $C$ are the predominant till units with only sporadic occurrences of Granite Till A. Glaciation resulted in these tills having similar directions of transport but differing clast provenance.

The dominant direction of glacier flow is to the south-southeast. Clast dispersal has shown that glaciers flowing in this direction have formed Granite Till A, Lawrencetown Till and Granite Till C. Granite Ti11 B and Granite Ti11 C are in part formed by the same ice flow event suggesting southeast dispersal in Granite Till B. A late southwestward ice flow is believed to have formed ablation tills west of Dauphinees Mill Lake indicating both southeastward and southwestward transport in Granite Till C.

The following generalizations can be made with regard to the distribution of the above mentioned tills and their clast provenance.

Granite Till A has a restricted occurrence and is usually found coring drumlins. It is overlain by younger t111 and is not normally collected during till sampling surveys. The clast composition has renewal distances varying from 1.7 to $2.4 \mathrm{~km}$ and is characterized by SMB granites indicating that Granite Till A is useful for inferring granite bedrock located within the renewal distance.

The Lawrencetown Till is a widespread surface ti11 in some areas of the SMB and is commonly encountered during till sampling and mapping surveys. The high non-granitic clast content of 40-90\% makes this till less desirable than the granite tills for use in mineral exploration on the SMB. It exhibits a large variation in renewal distance from 2.5 to $70 \mathrm{~km}$ and as a result contains highly variable contents of SMB clasts.

The 11thologic content of Granite Till B reflects the bedrock from which it was derived; changes in granite bedrock type are virtually mirrored in this till. Renewal distances in Granite Till B are short and vary from tens to hundreds of metres. Clasts in Granite Till B are reliable as aids in predicting the type of granite bedrock in areas of blanket till cover.

Granite T111 C is derived predominately from the SMB, but compared to Granite Till $B$ has incorporated clasts from a larger area. The renewal distances vary from $300 \mathrm{~m}$ to $6 \mathrm{~km}$ and consequently clast percentages vary corresponding1y. Granite Till $\mathrm{C}$ with short renewal distances may be oligomictic whereas with longer renewal distances the clast content is multi1ithologic.

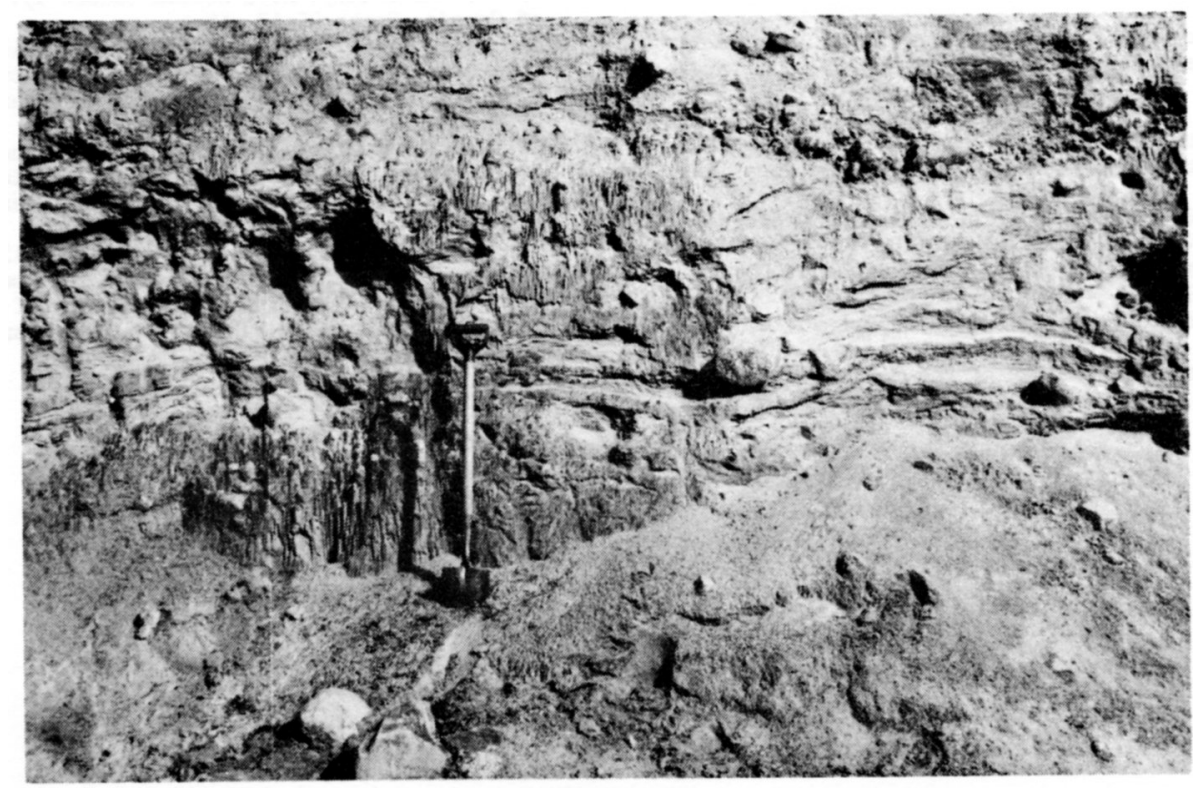

P1ate 3. Granite Till C exposed $3 \mathrm{~km}$ north of Chester.

The horizontal gravel/sand beds indicate re-working by glacial meltwater during till deposition. 


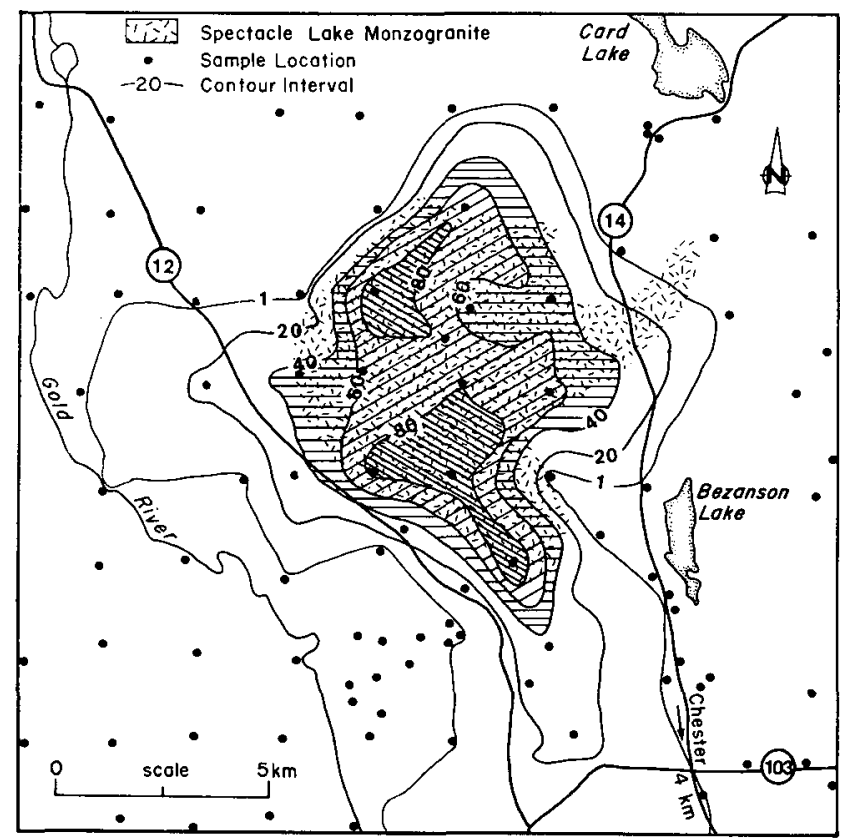

Fig. 10. Clast lithology map showing the dispersal of Spectacle Lake Leucomonzogranite clasts in Granite Ti11 C.

\section{ACKNOWLEDGEMENTS}

Funding was provided under the 1984-1989 CanadaNova Scotia Mineral Development Agreement. The authors thank R.R. Stea and P.J. Rogers for critically reviewing the manuscript. We also thank L.J. Ham and M.C. Corey for the discussions regarding the bedrock geology of their mapsheets. Drafting of the figures by the cartographic section at the Nova Scotia Department of Mines and Energy was greatly appreciated.

COREY. M.C. 1988. Geology of the Chester Map-sheet. Nova Scotia Department of Mines and Energy, Open F1le Map 88-001. Scale $1: 50,000$.

DREIMANIS. A. 1976. T111s: their origin and properties. In Glacial Till: An Inter-disciplinary Study. Edited by R.F. Legget. The Royal Society of Canada, Special Publications, 12. pp. $11-49$.

FINCK P.W. and GRAVES, R.M. 1987a. Glacial Geology of Halifax and Sambro. NTS Sheet $11 D / 12$ and $11 D / 05$. Nova Scot1a Department of Mines and Energy, Map 87-2. Scale 1:50.000.

FINCK, P.W., and GRAVES, R.M. 1987b. Glaclal Geology of Mount Un1acke. NTS Sheet 11D/13. Nova Scot1a Department of Mines and Energy, Map 87-1. Scale 1:50.000.

GRANT, D.R. 1963. Pebble L1thology of the T11ls of Southeast Nova Scotia. M.Sc. thesis, Dalhousie University, Halifax. Nova Scot1a, $235 \mathrm{p}$.
GRANT, D.R. 1975. Glaclal style and the Quaternary stratigraphic record in the Atlantic Provinces, Canada. In Report of Activities. Part B, Geological Survey of Canada, Paper 75-1B, pp. $109-110$

GRAVES, R.M. and FINCK, P.W. 1988. T111 Clast and Glacial Geologg of Chester. NTS Sheet 21A/09. Nova Scot1a Department of Mines and Energy, Map 88-1. Scale 1:50 000.

MACDONALD, M.A. . COREY, M.C., HAM, L.J., and HORNE, R.J. 1987. The geology of the South Mountain Batholith. NTS sheets $21 \mathrm{~A} / 09,21 \mathrm{~A} / 10,21 \mathrm{~A} / 15$ and $21 \mathrm{~A} / 16$ (west). In Mines and Minerais Branch, Report of Activities 1986. Edited by J.L. Bates and D.R. MacDonald. Nova Scotia Department of Mines and Energy, Report 87-1, pp. 107-122.

MACGILLIVRAY, G. 1983. Geological and geochemical surveys, Sh1p Harbour property, Hallfax County. Nova Scotia. Bili1ton Canada Limited, Nova Scotia Department of Mines and Energy. Assessment Report 11/D15B 07-H-97(03).

NIELSEN, E. 1976. The Composition and Origin of Wisconsinan Till In Mainland Nova Scot1a. Ph.D thes1s, Dalhousie University, Halifax, Nova Scot1a, 256 p.

PELTONIEMI. H. 1986. T111 11tlology and glacial transport in Kuhmo, eastern Finland. Boreas, 14, pp. 67-74.

PODOLAK, W.E., and SHILTS W.W. 1978. Some physical and chemical properties of t11l derived from the Meguma Group. southeast Nova Scotia. In Report of Activities, Part A, Geological Survey of Canada, Paper 78-1A, pp. 459-464.

PREST. W.H. 1896. Glacial succession in central Lunenburg. Nova Scotia. Proceedings and Transactions of the Nova Scotian Institute of Science, Halifax, 9, Session 1895-96. pp. $158-170$

PREST, V.K., GRANT, D.R., MACNEILL, R.H., BROOKS, I.A., BORNS, H.W., OGDEN, J.G. III, JONES, J.F., LIN, C.L. , HENNIGAR, T.W. and PARSONS, M.L. 1972. Quaternary geology. geomorphology and hydrogeology of the Atlant1c Provinces. 24th International Geological Congress, Excursion Guldebook. A61-C61, $79 \mathrm{p}$.

SALONEN, V.P. 1986. Glacial transport distance distributions of surface boulders in Finland. Geological Survey of Finland Bulletin, 338, $57 \mathrm{p}$.

SHAW. J. 1982. Forms associated with boulders in melt-out t1i1. In INQUA Symposia on the Genesis and L1thology of Quaternary Deposits, USA 1981/Argentina 1982. pp. 3-12.

STEA, R.R. 1982. The Properties, Correlation and Interpretation of Pleistocene Sediments in Central Nova Scot1a. M.Sc. thes1s, Dalhousie University, Halifax. Nova Scot1a, 215 p.

STEA, R.R. and FINCK, P.W. 1984. Patterns of glacier movement in Cumberland, Colchester. Hants and P1ctou Counties, northern Nova Scot1a. In Current Research, Part A, Geological Survey of Canada, Paper 84-1A, pp. 477-484.

STEA, R.R., FINCK, P.W., and WIGHTMAN, D.M. 1985. Quaternary geology and t1ll geochemistry of the western part of Cumberland County, Nova Scotia (sheet 9). Geological Survey of Canada. Paper 85-17, $58 \mathrm{p}$.

STEA, R.R., and FOWLER, J.H. 1979. Minor and trace element variations in Wisconsinan t111s, Eastern Shore Region, Nova Scotia. Nova Scotia Department of Mines and Energy. Paper $79-4,30 \mathrm{p}$.

STEA, R.R., and GRANT, D.R. 1982. Ple1stocene Geology and T111 Geochemistry of Southwestern Nova Scot1a (sheets 7 and 8). Nova Scot1a Department of Mines and Energy. Map 82-10. Scale $1: 100000$.

STEA, R.R., and O'REILLY, G.A. 1982. T111 geochemistry of the Meguma Terrane in Nova Scotia and 1ts metallogenic Implications. In Prospecting in Areas of Glaclated Terrain, 1982. Edited by P.H. Davenport. Canadian Institute of Mining and Metallurgy. pp. 82-104. 